\title{
Establishing consistency and best practice in the care of children and adolescents with eating disorders: developments at the Mater Children's Hospital (MCH) and Mater Child and Youth Mental Health Service (CYMHS)
}

Kelly Lamb ${ }^{1 *}$, Suzi Scholey ${ }^{2}$

From 2013 ANZAED Conference: Inspiring Change: Person and Context

Melbourne, Australia. 23-24 August 2013

One of the biggest challenges for an organisation and for clinicians and practitioners is implementing a new program or a new practice. Following an 18 month research project and the recruitment of an Eating Disorders Coordinator the $\mathrm{MCH}$ and Mater CYMHS have developed and implemented a number of protocols across its service to ensure consistency in the continuum of care and to ensure that treatment is in line with the best current evidence base.

Within the campus based services these have included;

- Development of a protocol for the CYMHS Inpatient Unit to provide structure and consistency to the admission of patients with restrictive eating disorders.

- Design and roll out of a Care Pathway for the Paediatric Medical Ward where medical crises associated with malnutrition are managed.

- Guidelines for triage of such patients in the Children's Emergency Department with parameters indicative of further consultation and/or admission.

- Off campus/outpatient service development has included;

- The implementation of Maudsley Family Based Therapy as the model of choice giving structure and consistency to outpatient treatment.

- Guidelines for community staff for medical monitoring nutritionally compromised children and adolescents.

* Correspondence: kelly.lamb@mater.org.au

${ }^{1}$ Mater Child and Youth Mental Health Service, Australia

Full list of author information is available at the end of the article
This presentation will refer to implementation science as a framework to describe the process and stages of development involved in the implementation of these projects.

This abstract was presented in the Children and Youth Treatment and Service Development stream of the 2013 ANZAED Conference.

\section{Authors' details}

'Mater Child and Youth Mental Health Service, Australia. ${ }^{2}$ Headspace Gold Coast, Australia.

Published: 14 November 2013

doi:10.1186/2050-2974-1-S1-061

Cite this article as: Lamb and Scholey: Establishing consistency and best practice in the care of children and adolescents with eating disorders: developments at the Mater Children's Hospital (MCH) and Mater Child and Youth Mental Health Service (CYMHS). Journal of Eating Disorders 2013 1(Suppl 1):061.

Submit your next manuscript to BioMed Central and take full advantage of:

- Convenient online submission

- Thorough peer review

- No space constraints or color figure charges

- Immediate publication on acceptance

- Inclusion in PubMed, CAS, Scopus and Google Scholar

- Research which is freely available for redistribution 